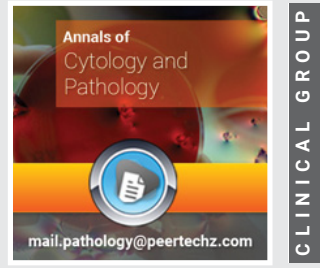

\title{
Evaluation of Different Guidelines for Cervical Cancer Screening and Management of Abnormal Cervical Cytology
}

\author{
M Samy Ismail ${ }^{\star *}$, Stephanie $\mathrm{Hsu}^{2}$, Muneera Ahmed \\ AlKhalifa ${ }^{3}$, Maryam Fuad Ali ${ }^{4}$, M Faëz Codabux ${ }^{5}$ and \\ Khalid Al-Sindi ${ }^{6}$
}

1Professor Mahmoud Samy Ismail, OBGYN Department, King Hamad University Hospital, Kingdom of Bahrain

${ }^{2}$ Dr. Stephanie Hsu, Research Department, King Hamad University Hospital, Kingdom of Bahrain

${ }^{3}$ Dr. Muneera Ahmed AlKhalifa, King Hamad University Hospital, Kingdom of Bahrain

${ }^{4}$ Dr. Maryam Fuad Ali, King Hamad University Hospital, Kingdom of Bahrain

${ }^{5}$ Dr. Mohammed Faëz Codabux, King Hamad University Hospital, Kingdom of Bahrain

${ }^{6}$ Professor Khalid Al-Sindi, Pathology Department, King Hamad University Hospital, Kingdom of

Bahrain

Received: 01 February, 2020

Accepted: 07 March, 2020

Published: 09 March, 2020

*Corresponding author: Mahmoud Samy Ismail, Professor, OBGYN Department, King Hamad University Hospital, Building 2435, Road 2835, Block 228, Busaiteen P.O Box 24343, Al Muharraq, Kingdom of Bahrain, Bahrain, Tel: +97335593048; E-mail: samyismael@hotmail.com

Keywords: Cervical cancer screening; Cervical cancer management; Abnormal cervical cytology

https://www.peertechz.com

Check for updates

\begin{abstract}
This is a comparison review article of the various guidelines that currently exist for cervical cancer screening. The guidelines used for comparison include the American College of Obstetricians and Gynecologists (ACOG), United States Preventive Services Task Force (USPSTF), American College of Physicians (ACP), American Cancer Society/American Society for Colposcopy and Cervical Pathology/American Society for Clinical Pathology (ACS/ASCCP/ASCP), Centers for Disease Control and Prevention (CDC), American Society for Colposcopy and Cervical Pathology, National Institute for Health and Care Excellence (NICE) guidelines, Singapore guidelines, National Health Service (NHS) Guidelines, The Canadian Task Force on Preventive Health Care, Society Of Obstetricians And Gynecologists Of Canada, World Health Organization (WHO), and The European Guidelines For Quality Assurance In Cervical Cancer Screening. As there is no universal screening guideline that is currently agreed upon, this article serves to highlight the key differences and resemblances between those guidelines with regards to the age of screening initiation and cessation, the screening intervals and management of abnormal screening results. Comparisons are made in the discussion, presented as individual tables, and comparison tables with regards to cytology and histology.
\end{abstract}

Tables summarizing the different guidelines available regarding screening for cervical cancer.

\section{Abbreviations}

ACOG: American College of Obstetricians and Gynecologists; USPSTF: United States Preventive Services Task Force; ACS: American Cancer Society; ASCCP: American Society for Colposcopy and Cervical Pathology; ASCP: American Society for Clinical Pathology; CDC: Centers for Disease Control and Prevention; ACP: American College of Physicians; NICE: National Institute for Health and Care Excellence; NHS: National Health Service; VIA: Visual Inspection with Acetic
Acid; HPV: Human Papillomavirus; ASCUS: Atypical Squamous Cells of Undetermined Significance; LSIL: Low Grade Squamous Intraepithelial Lesion; HSIL: High Grade Squamous Intraepithelial Lesion; ASC-H: Atypical Squamous Cells in which HSIL cannot be excluded; AGC: Atypical Glandular Cells; AIS: Adenocarcinoma in Situ; CIN: Cervical Intraepithelial Neoplasia; SCC: Squamous Cell Carcinoma; LEEP/LLETZ: Large Loop Excision of The Transformation Zone; CKC: Cold Knife Conization 


\section{NHS/NICE classification equivalency to Bethesda classification.}

Atypical squamous cells of undetermined significance ASCUS

Atypical squamous cells, cannot exclude HSIL

ASC-H

Low-grade dyskaryosis (mild)

LSIL

High-grade dyskaryosis (moderate-severe)

\section{Introduction}

The introduction of cervical cancer screening programs has accounted for a significant reduction in the incidence and mortality of cervical cancer [1]. In countries where cervical cancer screening is not available, cervical cancer remains the second most common cause of cancer as well as the second most common cause of cancer deaths among women [2]. Therefore, it is widely established that cervical cancer screening is undoubtedly essential as it permits early discovery of the disease and hence, early treatment and better prognosis. It also allows the detection of pre-malignant states, thus prevent the progression into invasive cancer [3]. Globally, various guidelines exist for cervical cancer screening as different countries and societies have developed different algorithms for screening. Those algorithms may agree about or vary in the age at which screening should be initiated and ceased, the intervals of screening as well as the steps involved in management of any abnormal screening result. Yet, there is no universe screening guideline that all countries, worldwide, may follow.

This article will discuss different cervical cancer screening programs that exist. It will highlight the key differences and resemblances between those guidelines with regards to the age of screening initiation and cessation, the screening intervals and management of abnormal screening results.

\section{Discussion}

Cervical Cancer Screening Guidelines: A Comparison Between Various Available Cervical Cancer Screening Guidelines

\section{Age of screening initiation}

The age to begin routine screening for cervical cancer is controversial. The American guidelines, including the guidelines of the American College of Obstetricians and Gynecologists (ACOG), the United States Preventive Services Task Force (USPSTF), the American Cancer Society (ACS), the American Society for Colposcopy and Cervical Pathology (ASCCP), the American Society for Clinical Pathology (ASCP), the American College of Physicians (ACP) and the American Society for Colposcopy and Cervical Pathology, agree to start routine screening for cervical cancer at the age of 21years [4]. However, the guidelines of Singapore and Canada, as well as the NICE and NHS guidelines, recommend starting screening at the age of 25years [5-8]. The World Health Organization (WHO), on the other hand, recommends beginning screening at age 30 for HIV-negative women [9]. Nevertheless, those guidelines give similar rationales behind their recommendations; cervical cancer is uncommon among younger women and to offer screening for that age group may lead to over-treatment and ultimately, more harm than good.

\section{Age of screening cessation}

The American guidelines for cervical screening, recommend that screening shall be ceased once a woman is above 65years of age and has no history of CIN2 or higher. However, this would be applicable only if either of the following is true; having 3 previous consecutive negative cytology results, or; having 2 previous consecutive negative co-test results, in the previous 10years with the most recent test being within 5years. Furthermore, screening shall also be discontinued for women who have had total hysterectomy with removal of the cervix and no history of CIN 2 or higher 4 . The guidelines of Singapore are similar, as they recommend no further screening for women aged above 65 if there was a previous negative smear in the last 3years [6]. As per the NICE guidelines and the NHS, women above the age of 65 shall only undergo cervical screening if there has been no screening done up to the age of 50years or if there is a recent abnormal cytology result. Otherwise, no screening should be offered in older women due to the infrequency of cervical cancer in this age group [7].

The Canadian guidelines, on the other hand, suggest stopping screening at the age of 70 for women who have had satisfactory screening, for instance 3 consecutively negative Pap test results in the previous 10years, as there is limited evidence of benefit to continue screening in this age group. Nevertheless, for women at 70years of age or older who have not yielded 3 negative test results, the recommendation is to continue adequate screening until these results have been obtained [5].

\section{Screening intervals}

The American guidelines recommend screening via cytology (Pap smear or liquid-based cytology) every 3years. However, if the woman wishes to lengthen the screening interval, a combination of cytology and HPV testing can be done every 5 years instead. However, it is not recommended to do HPV testing for average-risk women in the age group between 20 and 31. Moreover, there is insufficient evidence to support longer screening intervals for women between the age of 21 and 30 with 2 or more consecutive negative cytology results 4 . The screening intervals recommended by the NICE guidelines and the NHS are as follows: 3-yearly for women between the ages of 25-49years and 5-yearly for women between the ages of 50-65years [7]. (Please see Table 1, which summarizes the NHS guideline and Table 2, which summarizes the NHS guidelines). The Canadian guidelines recommend a 3-yearly screening interval for women between the ages 25-69years. This recommendation is based on 13 case-control and 2 cohort studies, which established that a screening interval of 5years or less provides a significant protection against cervical cancer [5], (Please see table 3, which summarizes The Canadian Task Force on Preventive Health Care screening for cervical cancer guidelines). The guidelines of Singapore recommend a 3-yearly screening interval as well for women between the ages 25-65years, however, more frequent screening if highrisk [6]. 
Table 1: National Institute for Health and Care Excellence (NICE) guidelines on screening for cervical cancer.

\begin{tabular}{|c|c|c|c|c|c|}
\hline \multicolumn{2}{|r|}{ Classification } & \multicolumn{4}{|c|}{ NICE guidelines } \\
\hline \multirow{2}{*}{\multicolumn{2}{|c|}{ Overview }} & $<25 y e a r$ old & 25-49years old & 50-65years old & $>65 y e a r s$ old \\
\hline & & No screening & $\begin{array}{l}\text { Initiate screening at the } \\
\text { age of 35years } \\
\text { Screen every 3years }\end{array}$ & $\begin{array}{l}\text { Screen every } \\
5 y e a r s\end{array}$ & $\begin{array}{l}\text { Screen only if no screening was done from } \\
50 \text { years or if a recent abnormal cervical cytology } \\
\text { was present }\end{array}$ \\
\hline & Borderline changes & \multicolumn{4}{|c|}{ - If HPV positive: Do colposcopy within 8weeks } \\
\hline & $\begin{array}{l}\text { Low-grade dyskaryosis } \\
\text { (mild) }\end{array}$ & \multicolumn{4}{|c|}{ - If HPV negative: Return to normal routine screening } \\
\hline & $\begin{array}{l}\text { High-grade dyskaryosis } \\
\text { (moderate-severe) }\end{array}$ & \multicolumn{4}{|c|}{ Do colposcopy within 4 weeks } \\
\hline & AIS & \multicolumn{4}{|c|}{ If 3 consecutive inadequate samples: Repeat cytology in 3 months } \\
\hline & $\begin{array}{l}\text { High-grade dyskaryosis? invasive } \\
\text { squamous cell carcinoma }\end{array}$ & \multirow{3}{*}{\multicolumn{4}{|c|}{ Do colposcopy within 2 weeks }} \\
\hline & $\begin{array}{l}\text { Invasive glandular neoplasia of } \\
\text { endocervical type }\end{array}$ & & & & \\
\hline & $\begin{array}{l}\text { Invasive glandular neoplasia non- } \\
\text { cervical }\end{array}$ & & & & \\
\hline \multirow{4}{*}{ Histology } & CIN 1 & - Generally base & $\begin{array}{r}\text { - Do a cytological sr } \\
\text { on the patient's preference } \\
\text { no reg }\end{array}$ & $\begin{array}{l}\text { ear with or withou } \\
\text { either provide trea } \\
\text { ession occurred af }\end{array}$ & $\begin{array}{l}\text { colposcopy at } 12 \text { months } \\
\text { ment or keep patient under observation and treat if } \\
\text { er } 24 \text { months }\end{array}$ \\
\hline & CIN 2 & \multirow{2}{*}{\multicolumn{4}{|c|}{ Treat either by ablation or large loop excision of the transformation zone }} \\
\hline & CIN 3 & & & & \\
\hline & Invasive carcinoma & \multicolumn{4}{|c|}{ Refer for surgical or non-surgical management } \\
\hline
\end{tabular}

Table 2: National Health Service (NHS) Guidelines on screening for cervical cancer.

\begin{tabular}{|c|c|c|c|c|c|c|}
\hline \multicolumn{3}{|c|}{ Classification } & \multicolumn{4}{|c|}{ NHS Guidelines } \\
\hline \multirow{2}{*}{\multicolumn{3}{|c|}{ Overview }} & \multirow{2}{*}{\multicolumn{2}{|c|}{\begin{tabular}{|c|}
24.5 \\
First invitation (to ensure that \\
women can be screened for the first \\
time by their 25 th birthday \\
No screening for age $<24.4$
\end{tabular}}} & $25-49$ & $50-6$ \\
\hline & & & & & $\begin{array}{l}\text { Screen every } \\
\text { 3years by LBC }\end{array}$ & $\begin{array}{l}\text { Screen } \Theta \\
\text { 5years by }\end{array}$ \\
\hline \multirow{6}{*}{ Cytology } & \multicolumn{2}{|c|}{ Borderline changes } & & & \multirow{2}{*}{\multicolumn{2}{|c|}{$\begin{array}{c}\text { Do colposcopy within } 6 \text { weeks } \\
\text { positive }\end{array}$}} \\
\hline & \multicolumn{2}{|c|}{ Low-grade dyskaryosis (mild) } & & & & \\
\hline & \multicolumn{2}{|c|}{$\begin{array}{l}\text { High-grade dyskaryosis } \\
\text { (moderate-severe) }\end{array}$} & & & \multirow{3}{*}{\multicolumn{2}{|c|}{ Do colposcopy within 2 we }} \\
\hline & \multicolumn{2}{|c|}{ High-grade dyskaryosis ?invasive SCC } & & & & \\
\hline & \multicolumn{2}{|c|}{$\begin{array}{l}\text { Invasive glandular neoplasia of } \\
\text { endocervical type }\end{array}$} & & & & \\
\hline & \multicolumn{2}{|c|}{$\begin{array}{l}\text { Invasive glandular neoplasia non- } \\
\text { cervical }\end{array}$} & & & \multicolumn{2}{|c|}{$\begin{array}{l}\text { Give an appointment wit } \\
\text { gynecologist within } 2 \text { wee }\end{array}$} \\
\hline \multirow{2}{*}{\multicolumn{3}{|c|}{ Classification }} & \multicolumn{4}{|c|}{ The Canadian Task Force on Preventive Health Care } \\
\hline & & & & $25-29$ & $30-6 c$ & \\
\hline Overview & $\begin{array}{l}\text { Routine screening not } \\
\text { recommended (strong } \\
\text { recommendation/high- } \\
\text { quality evidence)a }\end{array}$ & \multicolumn{2}{|c|}{$\begin{array}{l}\text { Routine screening not } \\
\text { recommended (weak } \\
\text { recommendation/ } \\
\text { moderate-quality } \\
\text { evidence) }\end{array}$} & $\begin{array}{l}\text { Routine screening } \\
\text { is recommended } \\
\text { every 3years (weak } \\
\text { recommendation/ } \\
\text { moderate-quality } \\
\text { evidence) }\end{array}$ & \multicolumn{2}{|c|}{$\begin{array}{l}\text { Routine screening is } \\
\text { recommended every 3years } \\
\text { (strong recommendation/ } \\
\text { high-quality evidence) }\end{array}$} \\
\hline
\end{tabular}

HPV co-testing: current recommendations do not

Screen every years by LBC have had recent abnormal tests or women who have not had adequate screening tests reported since age 50

ow-grade dyskaryosis (mild) 
cytology revealed atypical squamous cells of undetermined significance (ASCUS) and HPV co-testing was negative, it is recommended to preform routine age-based screening only. This is simply explained by the low risk of pre-cancerous or invasive lesions seen in HPV-negative women with ASCUS, as studies have shown [8]. However, if the result of the cytology were as either; atypical squamous cells-cannot exclude HSIL (ASC-H), Low Grade Squamous Intraepithelial Lesion (LSIL), high Grade Squamous Intraepithelial Lesion (HSIL) or Atypical Glandular Cells (AGC), it is recommended to do HPV cotesting after 12months with referral for colposcopy $[4,8]$. In addition, for women with history of CIN 2 or higher, the ACOG recommends to screen via cytology every 3years for a period of 2oyears after the initial post-treatment surveillance period. This would also be applicable if the woman underwent a total or supra-cervical hysterectomy $[4,8]$. The American Society for Colposcopy and Cervical Pathology: The main 2 categories of population regarding this guideline is based on age group, that is, people younger than 21years old and people older than 21years old. Initiation of screening is recommended 3years after first sexual intercourse or at the age of 21 , whichever comes first in the less than 21years old population. Screening is advised every 3years in the older group. For any age group, if HPV test is positive and cytology is negative, a conservative approach should be considered, that is repeating both test in 12months' time. However, if both HPV test and cytology are positive, referral to colposcopy is recommended. In the <21year old patients, a cytology revealing ASCUS or LSIL needs to be repeated in 12months and if the change still persists for more than 24 months, then referral to colposcopy is indicated. If the lesion shows HSIL, colposcopy is recommended. In the event of a cytology showing AGC initially and on repeated cytology in 24 months, referral for colposcopy is advised. Patients having CIN 1 lesions on colposcopy will need repeat cytology in 12months and if the changes still persist for 24 months colposcopy will be required. In the >21year old population, in case cytology shows ASCUS, 3 options are available, HPV test, cytology in 6 or 12months and colposcopy. In case colposcopy is chosen and revealed negative, repeat cytology in 6 or 12months or HPV test in 12months. If HPV test done is positive or repeated cytology done in 6 or 12months shows ASCUS or HPV test done in 12months is positive, colposcopy is advisable. Any LSIL changes noted on cytology should be referred to colposcopy. If colposcopy is found to be positive for any changes except for CIN 2 and CIN 3, cytobrush and endocervical curette is recommended; otherwise HPV test is recommended in 12months or cytology in 6 and 12months. If HSIL is found on cytology, the initial test recommended are diagnostic procedures (immediate loop electrosurgical excision) or colposcopy with endocervical assessment. If no CIN 2 or 3 was found on colposcopy and endometrial sampling is negative, diagnostic procedures or cytology or colposcopy every 6months can be considered. However, if HSIL persists at 6 or 12months, referral for excision should be considered. In cytology showing AGC, colposcopy with endocervical sampling and HPV test are recommended, especially in the suspicion of high risk of endometrial cancer. In the event of a cytology showing AIS, diagnostic excisional procedure is recommended. For CIN 1 persisting for 2years, observe the changes but if it was preceded by HSIL or AGC-NOS, then diagnostic excision or cytology and colposcopy in 6 and 12months are recommended. If there is any unsatisfactory colposcopy or positive sampling or previous treatment, refer for excision. Please see summary tables 4-9, which covers each of the six discussed guidelines.

In addition, please see Table 10, which compares cervical cancer screening guidelines based on cytology and Table 11, which compares cervical cancer screening guidelines based on histology.

\section{NICE guidelines}

If cytology reveals ASCUS or LSIL, the following action depends on the HPV co-testing result. If HPV is positive, colposcopy should be done within 8weeks. However, if HPV

Table 4: American College of Obstetricians and Gynecologists (ACOG) guidelines on screening for cervical cancer

\section{Classification

American College of Obstetricians and Gynecologists (ACOG)

$<21$ year old

21-30year old

31-65year old

$>65 y e a r$ old

Screening is ceased in women above the age of 65years with no history of $\geq$ CIN 2 with either

No screening is done for women under the age of 21years with the exception of HIV-positive or immunecompromised women
A 3-yearly screen via cervical cytology only
A 5-yearly screening via cervical 3 consecutive negative cytology results or 2 consecutive cytology and high-risk HPV DNA negative co-test results over the past 10years, with the testing OR a 3-yearly screen via most recent test being done within the last 5years cervical cytology only

Screening is also stopped for women who have undergone total hysterectomy and have no history of $\geq \mathrm{CIN} 2$

\section{HPV test positive ASCUS \\ Cytology ASC-H LSIL HSIL CIN 1 CIN 2 CIN 3} Histology
Colposcopy

Return back to routine screening if a HPV co-test was done and indicated a negative result

Refer to colposcopy and do a cotest with HPV after 12 months

Treatment will be given and later, the patient will return back to routine age-based screening for a period of 20years from the initial post-treatment surveillance (past age 65years if necessary)

For women with total hysterectomy and history of either CIN 2 or higher in previous 20years or cervical cancer ever, screen with cervical cytology alone every 3years for $20 y e a r s$ after initial post-treatment surveillance period

AIS For women with a supracervical hysterectomy and history of CIN 2 or higher perform routine screening every 3years for 20years after initial post treatment surveillance period 
Table 5: United States Preventive Services Task Force (USPSTF) guidelines on screening for cervical cancer. Classification United States Preventive Services Task Force (USPSTF)
$<21$ year old
21-30year old
31-65year old

Screen via cytology (Pap smear or liquid-based cytology) every 3years

Overview No screening is recommended
If a longer screening interval is desired, screening with a combination of cytology and HPV co-testing may be done every 5 years
No screening is recommended if there were adequate normal previous screening tests and the women is no other-wise at high risk for cervical cancer Adequate previous screening may be defined as 3 consecutive negative cytology results or 2 consecutive negative co-test results over the past $10 y e a r s$, with the most recent test being done within the last 5years

Screening is also stopped for women who have undergone total hysterectomy with removal of the cervix and have no history of $\geq \mathrm{CIN} 2$

Table 6: American College of Physicians (ACP) on screening for cervical cancer

\section{Classification}

\section{1-30year old}

Start screening asymptomatic average-risk women at the age of

Overview

\section{No screening is} done

$$
\text { 21years }
$$

Do a 3-yearly screen with cytolo

than once every 3years

Do not perform HPV testing in average-risk women $<30$ years old

\section{American College of Physicians (ACP)}

\section{1-65year old}

$>65$ year old

Do a 3-yearly screen with cytology

A combination of Pap smear and HPV

testing once every 5years may be used

in women who prefer

screening less frequently than once every 3years
Screening is ceased in women above the age of 65years with no history of $\geq \mathrm{CIN} 2$ with either

3 consecutive negative cytology results or 2 consecutive negative co-test results over the past 10years, with the most recent test being done within the last 5years

Table 7: American Cancer Society/American Society for Colposcopy and Cervical Pathology/American Society for Clinical Pathology (ACS/ASCCP/ASCP) on screening for cervical cancer.

Do not screen women aged Screen with cytology alone every $<21$ years old regardless of

Overview risk factors including the age at which sexual activity was initiated

PV test positive

Cytology ASCUS

ASC-H

LSIL

HSIL

CIN 1

Histology CIN 2 CIN 3
Begin cervical cancer screening at the age of 21years

\section{1 - 65year old >65year old}

Screening is ceased in women above the age of $65 y e a r s$ with no history of $\geq \mathrm{CIN} 2$ with either 3 consecutive negative cytology results or 2 3years

There is insufficient evidence to support longer screening intervals for women in this age group with $\geq 2$ consecutive negative cytology results Co-testing with cytology consecutive negative co-test results over the and HPV testing every past 10years, with the most recent test being 5years or cytology alone done within the last 5years every 5years Screening is also stopped for women who have undergone total hysterectomy and have no history of $\geq$ CIN 2 .

Screening practice is not altered based on HPV vaccination status Do a HPV-genotype specific-testing for HPV 16 or HPV 16/18 immediately: - If HPV 16 or HPV 16/18 positive: Refer to colposcopy

- If HPV 16 or HPV 16/18 negative: Repeat co-testing in 12months Resume routine screening

Do HPV co-testing after 12 months with referral for colposcopy Adenocarcinoma in situ for at least 20years

Table 8: Centers for Disease Control and Prevention (CDC) on screening for cervical cancer.

\begin{tabular}{l}
\hline \multicolumn{1}{|c|}{ Classification } \\
\hline Overview
\end{tabular}
Centers for Disease Control and Prevention (CDC)

21 - 30year old 31 - 65year old

Same guidelines as (ACS/ASCCP/ASCP) are followed

$>65$ year old

or without colposcopy at 12 months. Depending on the patient's desire, treatment can be initiated for CIN 1 or the patient may opt to watch and wait and treat only if no regression occur within 24 months. However, if the histology reveals CIN grade 2 or grade 3; the lesion will be treated with either ablation or large loop excision of the transformation zone [7]. Please see Table 7 at the end of this review article, which summarizes the discussed guideline. 
Table 9: American Society for Colposcopy and Cervical Pathology on screening for cervical cancer.

\begin{tabular}{|c|c|c|c|c|c|}
\hline \multicolumn{2}{|c|}{ Classification } & \multicolumn{4}{|c|}{ American Society for Colposcopy and Cervical Pathology } \\
\hline \multirow{2}{*}{\multicolumn{2}{|c|}{ Overview }} & $<21$ year old & 21-30year old & 31-65year old & $>65 y e a r$ old \\
\hline & & $\begin{array}{l}\text { Initiate screening with cytology 3years } \\
\text { after sexual intercourse } \\
\text { OR at the age of } 21 \text { (whichever comes first) }\end{array}$ & Screen is recommended every 3years & & \\
\hline \multirow{7}{*}{ Cytology } & $\begin{array}{l}\text { HPV test } \\
\text { positive }\end{array}$ & \multicolumn{4}{|c|}{$\begin{array}{l}\text { - If HPV test is positive and cytology is negative: conservative follow-up is advised with repeat co-testing at } 12 \text { months } \\
\text { - If HPV test is positive and cytology is positive: referral to colposcopy is recommended }\end{array}$} \\
\hline & ASCUS & $\begin{array}{l}\text { Repeat cytology in } 12 \text { months, if the change } \\
\text { persists for more than } 24 \text { months then refer } \\
\text { to colposcopy }\end{array}$ & \multicolumn{3}{|c|}{$\begin{array}{l}\text { 1) HPV test is preferred for triage and colposcopy is advisable for positive HPV test } \\
\text { 2) Repeat cytology in } 6 \text { months or } 12 \text { months } \\
\text { 3) o an immediate colposcopy } \\
\text { colposcopy done was negative: repeat cytology in } 6 \text { months and } 12 \text { months OR HPV test in } \\
12 \text { months } \\
\text { ated cytology in the following } 6 \text { or } 12 \text { months still shows ASCUS, then refer again to colposcopy } \\
\text { - if HPV test done in the following } 12 \text { months is still positive, then refer to colposcopy }\end{array}$} \\
\hline & ASC-H & & \multicolumn{3}{|c|}{ Refer to colposcopy } \\
\hline & LSIL & $\begin{array}{l}\text { Repeat cytology in } 12 \text { months, if the change } \\
\text { persists for more than } 24 \text { months then refer } \\
\text { to colposcopy }\end{array}$ & \multicolumn{3}{|c|}{$\begin{array}{l}\text { - if colposcopy is positive for any changes, cytobrush or Endocervical curette is recommended } \\
\text { - if colposcopy is positive (NOT CIN } 2 \text { OR CIN 3), HPV test is recommended in } 12 \text { months OR cytology } \\
\text { in } 6 \text { months and } 12 \text { months respectively }\end{array}$} \\
\hline & HSIL & Refer to colposcopy & \multicolumn{3}{|c|}{$\begin{array}{l}\text { 1) Initial tests recommended are: } \\
\text { - diagnostic procedure (High risk and done with childbearing) } \\
\text { - colposcopy with Endocervical assessment } \\
\text { Iostic OR cytology and colposcopy every } 6 \text { months till the tests are negative } \\
\text { 3) if HSIL persists at } 6 \text { OR } 12 \text { months, refer for excision }\end{array}$} \\
\hline & AGC & $\begin{array}{l}\text { If the change persists for more than } \\
24 \text { months then refer to colposcopy }\end{array}$ & \multicolumn{3}{|c|}{$\begin{array}{l}\text { Colposcopy with Endocervical sampling and HPV test are recommended (especially high risk of } \\
\text { endometrial Cancer) } \\
\text { - if AGC unremarkable and HPV is positive, then refer to cytology and HPV in } 6 \text { months } \\
\text { - if HPV is negative, refer to cytology and HPV in } 12 \text { months }\end{array}$} \\
\hline & AIS & & \multicolumn{3}{|c|}{ Diagnostic excisional procedure } \\
\hline \multirow{4}{*}{ Histology } & CIN 1 & $\begin{array}{l}\text { Repeat cytology in } 12 \text { months, if the change } \\
\text { persists for more than } 24 \text { months then refer } \\
\text { to colposcopy }\end{array}$ & \multicolumn{3}{|c|}{$\begin{array}{l}\text { 1) If persistent for } 2 y e a r s, \text { observe the changes } \\
\text { - if preceded by HSIL OR AGC-NOS, then diagnostic excision is recommended OR cytology and } \\
\text { colposcopy in } 6 \text { months and } 12 \text { months } \\
\text { 2) If unsatisfactory colposcopy OR positive sampling OR previous treatment, refer for excision }\end{array}$} \\
\hline & CIN 2 & 1) Observation & \multirow{2}{*}{\multicolumn{3}{|c|}{$\begin{array}{l}\text { 1) + satisfactory colposcopy }=>\text { ablation OR diagnostic excision } \\
\text { 2) monitor post treatment } \\
\text { - HPV } \\
\text { - cytology alone or with HPV also }\end{array}$}} \\
\hline & CIN 3 & $\begin{array}{l}\text { 2) colposcopy and cytology every } 6 \text { months } \\
\text { till 2years } \\
\begin{array}{l}\text { 3) Treatment with excision or ablation } \\
\text { 4) if CIN } 2 \text { => observation preferred } \\
\text { 5) CIN } 3 \text { => treatment }\end{array}\end{array}$ & & & \\
\hline & AIS & & \multicolumn{3}{|c|}{$\begin{array}{l}\text { HPV, colposcopy, endocervical sampling in } 6 \text { months } \\
\text { - AGC-favoring neoplasia or AIS by cytology and no invasion => Excisional procedure } \\
\text { - AIS by histology => hysterectomy }\end{array}$} \\
\hline
\end{tabular}

\section{The Society of obstetricians and gynecologists of ca- nada guidelines}

If a cytology result showed borderline changes, i.e. ASCUS, colposcopy should be done within 12weeks. If a lesion is found on colposcopy, a biopsy will be obtained. However, if no lesion was found, a biopsy of the transformation zone will be obtained. Nevertheless, if such result was found in a woman less than 21years of age, cytology should be repeated. If a cytology result revealed atypical squamous cells in which HSIL (ASC-H) cannot be excluded, colposcopy should be done within 6weeks. If the cytology shows mild dyskaryosis (i.e. LSIL), a similar guideline as above will be followed, i.e.; colposcopy within 12weeks, biopsy of any found lesion or biopsy of the transformation zone if no lesion was found. And similarly, if the age group was below 21years, only cytology will be repeated. Moreover, any moderate or severe dyskaryosis (i.e. HSIL) will necessitate a colposcopy within 4weeks. If no lesion was found on colposcopy, endocervical curettage or directed biopsy will be done. However, if a lesion was to be found and the transformation zone could not be seen and the endocervical curettage and/or biopsy were negative; a diagnostic excisional procedure will be required. Whenever atypical glandular cells or adenocarcinoma in-situ were to be found on cytology, colposcopy and endocervical curettage are to be done within 6weeks. Besides, if the age is above 35years and per-vaginal bleeding is evident, endometrial sampling will be required. If the colposcopy shows no lesion, a diagnostic excisional procedure will be done. Furthermore, if histology then shows CIN1, the patient will be kept under observation and either cytology at 12months or colposcopy at 12 months will be done. On the other hand, a CIN2 or 3 in an age group more than 25years will necessitate treatment via excision. If a positive margin was found, colposcopy and directed $\mathrm{Bx}$ and/or endocervical curettage will be required. In case of any recurrence or persistent lesions, excision will be required as well. Please see Table 12, which summarizes the discussed guideline.

\section{Singapore guidelines}

Firstly, based on the cytology result, if atypical squamous cells of undetermined significance were found (ASCUS), PAP 
Table 10: Comparison of Cervical Cancer Screening Guidelines based on Cytology.

\begin{tabular}{|c|c|c|c|c|c|c|c|}
\hline \multicolumn{8}{|c|}{ Cytology } \\
\hline Guidelines & Age Group & ASCUS & LSIL & ASC-H & HSIL & AGC & AIS \\
\hline $\begin{array}{l}\text { The American } \\
\text { Guidelines }\end{array}$ & $21-65$ & $\begin{array}{l}\text { Resume routine } \\
\text { screening }\end{array}$ & \multicolumn{3}{|c|}{ Refer to colposcopy and do a co-test with HPV after 12 months } & & \\
\hline & $<21$ & \multicolumn{2}{|c|}{$\begin{array}{l}\text { Repeat cytology in } 12 \text { months, if persists for } \\
\text { more than } 24 \text { months refer to colposcopy }\end{array}$} & & Refer to colposcopy & $\begin{array}{l}\text { If persists for more } \\
\text { than } 24 \text { months refer } \\
\text { to colposcopy }\end{array}$ & \\
\hline $\begin{array}{l}\text { American } \\
\text { Society for } \\
\text { Colposcopy } \\
\text { and Cervical } \\
\text { Pathology }\end{array}$ & $21-65$ & $\begin{array}{l}\text { 1) Triage: HPV test } \\
\text { and colposcopy } \\
\text { 2) Repeat cytology } \\
\text { in } 6 \text { months or } \\
\text { 12months OR do } \\
\text { an immediate } \\
\text { colposcopy } \\
\text { 3) If colposcopy } \\
\text { was negative: } \\
\text { repeat cytology } \\
\text { in } 6 \text { months or } \\
12 \text { months } \\
\text { - repeat cytology } \\
\text { in } 6 \text { or } 12 \text { months } \\
\text {-> ASCUS => } \\
\text { colposcopy } \\
\text { - HPV test in } \\
12 \text { months -> } \\
\text { positive => } \\
\text { colposcopy }\end{array}$ & $\begin{array}{c}\text { 1) Colposcopy } \\
\text { - negative => cytobrush or } \\
\text { Endocervical curette } \\
\text { - positive (NOT CIN } 2 / 3 \text { ) } \\
=>\text { HPV test in } 12 \text { months } \\
\text { OR cytology in } 6 \text { months } \\
\text { and } 12 \text { months }\end{array}$ & $\begin{array}{l}\text { Refer to } \\
\text { colposcopy }\end{array}$ & $\begin{array}{c}\text { 1) Initial } \\
\text { - diagnostic procedure } \\
\text { (High risk and done with } \\
\text { childbearing) } \\
\text { - colposcopy with } \\
\text { Endocervical assessment } \\
\text { 2) diagnostic/cytology and } \\
\text { colposcopy every 6months } \\
\text { till above negative } \\
\text { 3) if HSIL persists at } \\
\text { 6/12months => excision }\end{array}$ & $\begin{array}{l}\text { Colposcopy with } \\
\text { Endocervical } \\
\text { sampling and HPV } \\
\text { test (especially high } \\
\text { risk of endometrial } \\
\text { Cancer) } \\
\text { - if AGC } \\
\text { unremarkable and } \\
\text { HPV positive => } \\
\text { cytology and HPV in } \\
6 \text { months } \\
\text { and HPV negative => } \\
\text { cytology and HPV in } \\
12 \text { months }\end{array}$ & $\begin{array}{l}\text { Diagnostic excisional } \\
\text { procedure }\end{array}$ \\
\hline NICE & $25-65$ & \multicolumn{2}{|c|}{$\begin{array}{c}\text { - If HPV positive: do colposcopy within 8weeks } \\
\text { - If HPV negative: return to normal routine } \\
\text { screening }\end{array}$} & & $\begin{array}{l}\text { Do colposcopy within } \\
\text { 4weeks }\end{array}$ & & $\begin{array}{l}\text { If } 3 \text { consecutive } \\
\text { inadequate samples: } \\
\text { repeat cytology in } \\
\text { 3months }\end{array}$ \\
\hline Singapore & $25-65$ & $\begin{array}{c}\text { Repeat smear in } \\
6 \text { months: if positive } \\
\text { refer to colposcopy } \\
\text { / if negative repeat } \\
\text { again in } 6 \text { months, } \\
\text { then if still negative } \\
\text { return to routine } \\
\text { screening }\end{array}$ & $\begin{array}{l}\text { 1. If mild dyskaryosis or } \\
\text { not otherwise specified: } \\
\text { Colposcopy } \\
\text { 2. If HPV effect: Repeat in } \\
6 \text { months: } \\
\text { a. If negative: Repeat in } \\
1 \text { year > if still negative } \\
\text { resume routine screening } \\
\text { b. If still HPV effect or } \\
\text { more severe abnormality: } \\
\text { colposcopy }\end{array}$ & $\begin{array}{l}\text { Refer to } \\
\text { colposcopy }\end{array}$ & $\begin{array}{l}\text { 1. If moderate or severe } \\
\text { dyskaryosis: colposcopy } \\
\text { 2. If severe dyskaryosis and } \\
\text { cannot rule out invasive } \\
\text { Cancer: Urgent colposcopy }\end{array}$ & Refer to colposcopy & $\begin{array}{l}\text { Endocervical } \\
\text { adenocarcinoma in-situ: } \\
\text { colposcopy }\end{array}$ \\
\hline NHS & $25-65$ & \multicolumn{2}{|c|}{ Do colposcopy within 6weeks if HPV positive } & & $\begin{array}{l}\text { Do colposcopy within } \\
\text { 2weeks }\end{array}$ & & \\
\hline & $<21$ & Repe & at cytology & & Colposcopy within 4 weeks & & \\
\hline $\begin{array}{l}\text { Society Of } \\
\text { Obstetricians } \\
\text { And } \\
\text { Gynecologists } \\
\text { Of Canada }\end{array}$ & $21-65$ & $\begin{array}{l}\text { Do colposcopy with } \\
\text { found: do a biopsy, if } \\
\text { biopsy of the }\end{array}$ & $\begin{array}{l}\text { in } 12 \text { week: if a lesion was } \\
\text { f no lesion was found: do a } \\
\text { transformation zone }\end{array}$ & $\begin{array}{l}\text { Colposcopy within } \\
\text { 6weeks }\end{array}$ & $\begin{array}{l}\text { Do colposcopy within } \\
\text { 4weeks, if no lesion } \\
\text { found: do endocervical } \\
\text { curettage/directed biopsy. } \\
\text { If lesion was found and } \\
\text { transformation zone was } \\
\text { not seen and endocervical } \\
\text { curettage and/or biopsy } \\
\text { were negative: do a } \\
\text { diagnostic excisional } \\
\text { procedure }\end{array}$ & \multicolumn{2}{|c|}{$\begin{array}{l}\text { Do colposcopy and endocervical curettage } \\
\text { within } 6 \text { weeks (plus endometrial sampling if } \\
\text { bleeding and age more than 35years). } \\
\text { If no lesion was found on colposcopy: do a } \\
\text { diagnostic excisional procedure }\end{array}$} \\
\hline
\end{tabular}

Any positive cytology ( $\geq$ ASCUS): do colposcopy:

- If colposcopy was negative: repeat screening in 3year time

- If colposcopy was positive and no biopsy was done: Treat with cryotherapy if eligible or with LEEP if not. Later, do a follow-up screen

- If colposcopy was positive and biopsy was done: for $\geq$ CIN2 treat with cryotherapy or LEEP and then do a follow-up screen in a 1-year time. However, if biopsy shows $\mathrm{a} \leq \mathrm{CIN} 1$ repeat screening in 3-year time.

- If cancer was suspected: refer the patient for appropriate diagnosis and treatment

The European

Guidelines

For Quality

Assurance In Cervical Cancer

Screening
Re-test in

6-12months or refer Refer to colposcopy to colposcopy 
Table 11: Comparison of Cervical Cancer Screening Guidelines based on Histology.

\begin{tabular}{|c|c|c|c|c|c|}
\hline \multicolumn{6}{|c|}{ Histology } \\
\hline Guidelines & Age Group & CIN1 & CIN 2, CIN 3 & Invasive carcinoma & AIS \\
\hline $\begin{array}{l}\text { The American } \\
\text { Guidelines }\end{array}$ & $21-65$ & & $\begin{array}{l}\text { Continue to screen women } \\
\text { following spontaneous regression } \\
\text { or appropriate management of } \\
\text { CIN 2, CIN 3, or } \\
\text { Adenocarcinoma in situ for at } \\
\text { least 20years }\end{array}$ & & \\
\hline \multirow[t]{2}{*}{$\begin{array}{l}\text { American Society } \\
\text { for Colposcopy and } \\
\text { Cervical Pathology }\end{array}$} & $<21$ & $\begin{array}{l}\text { Repeat cytology in } 12 \text { months, if persists } \\
\text { for more than } 24 \text { month refer to colposcopy }\end{array}$ & $\begin{array}{l}\text { 1) Observation } \\
\text { 2) colposcopy and cytology every } \\
6 \text { months till 2years } \\
\text { 3) Treatment with excision or } \\
\text { ablation } \\
\text { 4) if CIN } 2=>\text { observation } \\
\text { preferred } \\
\text { 5) CIN } 3 \text { => treatment }\end{array}$ & & \\
\hline & $21-65$ & $\begin{array}{l}\text { 1) If persistent for } 2 \text { years => observation } \\
\text { - if preceded HSIL/AGC-NOS => diagnostic } \\
\text { excision OR cytology and colposcopy in } 6 \\
\text { months and } 12 \text { months } \\
\text { 2) unsatisfactory colposcopy/positive } \\
\text { sampling/ previous Treatment => Excision }\end{array}$ & $\begin{array}{c}\text { 1) + satisfactory colposcopy => } \\
\text { ablation OR diagnostic excision } \\
\text { 2) monitor post-treatment } \\
\text { - HPV } \\
\text { - cytology alone or with HPV also }\end{array}$ & & $\begin{array}{l}\text { HPV, colposcopy, endocervical } \\
\text { sampling in 6months } \\
\text { - AGC-favoring neoplasia or AIS } \\
\text { by cytology and no invasion => } \\
\text { Excisional procedure } \\
\text { - AIS by histology => hysterectomy }\end{array}$ \\
\hline NICE & $25-65$ & $\begin{array}{l}\text { - Do a cytological smear with or without } \\
\text { colposcopy at } 12 \text { months } \\
\text { - Generally based on the patient's } \\
\text { preference; either provide treatment or } \\
\text { keep patient under observation and treat if } \\
\text { no regression occurred after } 24 \text { months }\end{array}$ & $\begin{array}{l}\text { Treat either by ablation or } \\
\text { large loop excision of the } \\
\text { transformation zone }\end{array}$ & $\begin{array}{l}\text { Refer for surgical } \\
\text { or non-surgical } \\
\text { management }\end{array}$ & \\
\hline Singapore & $25-65$ & $\begin{array}{l}\text { Controversial: } 2 \text { options available: } \\
\text { 1. Treat with ablation or excision then } \\
\text { follow-up with PAP smear at } 3-6 \text { months, } \\
\text { PAP smear and colposcopy at } 12 \text { months } \\
>\text { yearly PAP smear } x 4 \text { > return to routine } \\
\text { screening } \\
\text { 2. Observe and repeat PAP smear and } \\
\text { colposcopy }+/ \text { - biopsy in } 6 \text { months }\end{array}$ & $\begin{array}{c}\text { After treatment screen with PAP } \\
\text { smear at } 3-6 \text { months > PAP smear } \\
\text { and colposcopy at } 12 \text { months }> \\
\text { PAP smear } 6 \text { monthly for } 2 \text { nd year } \\
>\text { yearly PAP smear }\end{array}$ & & \\
\hline $\begin{array}{c}\text { Society Of } \\
\text { Obstetricians And } \\
\text { Gynecologists Of } \\
\text { Canada }\end{array}$ & $21-65$ & $\begin{array}{l}\text { Observation and repeat cytology or do } \\
\text { colposcopy at } 12 \text { months }\end{array}$ & $\begin{array}{l}\text { Excisional procedure } \\
\text { If positive margin: colposcopy } \\
\text { and directed Biopsy and/or } \\
\text { endocervical curettage } \\
\text { If recurrent or persistent lesions: } \\
\text { Excision }\end{array}$ & $\begin{array}{l}\text { Do colposcopy within } \\
2 \text { weeks with biopsy }\end{array}$ & $\begin{array}{l}\text { Diagnostic excisional procedure } \\
\text { OR type } 3 \text { transformation zone } \\
\text { excision } \\
\text { If positive margin: do a second } \\
\text { excisional procedure } \\
\text { After treatment: If woman } \\
\text { completed her family: consider } \\
\text { hysterectomy. If family still no } \\
\text { completed and negative margin: } \\
\text { further excisional procedure } \\
\text { unnecessary }\end{array}$ \\
\hline
\end{tabular}

smear will be repeated in 6 months. If the repeated smear was positive, patient will be referred to colposcopy, however, if negative, it will be repeated again in 6months, then if a persistent negative smear was found, the patient will be referred back to routine screening. Moreover, if atypical squamous cells in which HSIL (ASC-H) cannot be excluded, the patient will be referred immediately to colposcopy 6 .

\section{For Low Grade Squamous Intraepithelial Lesion (LSIL)}

- If mild dyskaryosis was found or not otherwise specified, the patient will be referred to colposcopy.

- If a HPV effect was found, cytology will be repeated in 6 months. If the repeated cytology was negative, it will be repeated again in 1year after which if persistent negative smear was found, routine screening schedule will be resumed. However, if the initial repeated cytology showed a HPV effect or more significant abnormality, colposcopy will be done.

\section{For High Grade Squamous Intraepithelial Lesion (HSIL)}

Moderate or severe dyskaryosis: referral to colposcopy will be done and an urgent referral if severe dyskaryosis in which invasive carcinoma cannot be ruled out 6 . If atypical glandular cells or endocervical adenocarcinoma in-situ was found, the patient will be referred to colposcopy.

\section{Any inflammatory smear will require the following ac-} tions

- Treatment of any infection or atrophy then repetition of smear in 4-6months. 
- If $2^{\text {nd }}$ smear has similar changes, the same action as per 1st smear will be done.

- If $3^{\text {rd }}$ smear has again similar changes, the patient will be referred to a gynecologist.

- If changes resolve after 1 st or 2 nd smears, routine screening will be resumed.

Regarding the recommended approaches towards histological findings, the management of a grade 1 cervical intraepithelial lesion is controversial. One possible approach is to treat the lesion via ablation or excision then follow it up with PAP smear at 3-6months then PAP smear and colposcopy at 12months then a yearly PAP smear (four smears) and then finally return to routine screening. The other option is to observe the lesion and repeat PAP smear and colposcopy $+/-$ biopsy in 6months [6].

Grade 2 and 3 cervical intraepithelial lesions will require treatment. Following treatment, screening via PAP smear will be done at 3-6months then PAP smear and colposcopy at 12months then PAP smear 6monthly for the 2nd year and finally a yearly PAP smear [6].

Please see table 13, which summarizes the discussed guideline.

The WHO Guidelines for Screening and Treatment of Precancerous Lesions for Cervical Cancer Prevention:

The new WHO guidelines recommend a screen-and treat approach for cervical neoplasms. As the name suggests, this strategy involves screening followed by initiation of appropriate treatment once screening is positive [9]. Screening is initiated at the age of 30 . There are no recommendations to preform screening for women aged less than 30years of age [9]. The guidelines suggest that screening via HPV testing is superior to screening with cytology (PAP smear). However, the guidelines provide algorithms for both screening methods (9).

\section{First, if screening with HPV was done, the following} steps are taken

- If HPV negative: repeat screening every 5years minimum.

- If HPV positive > do VIA to assess eligibility for treatment with cyotherpay and to exclude a cervical cancer.

- If VIA negative: repeat screening in 1-year time and then 3-5yearly .

- If VIA positive: Treat with cryotherpay if eligible or with LEEP if not. Later, do a follow-up screen in a 1year time.

- If cancer was suspected: refer the patient for appropriate diagnosis and treatment.

Alternatively, if HPV test was positive, colposcopy can be done instead of VIA

- If colposcopy was negative: Repeat screening in 3years' time.

- If colposcopy was positive and no biopsy was done: Treat with cryotherapy if eligible or with LEEP if not. Later, do a follow-up screen in a 1year time.

Table 12: Society Of Obstetricians And Gynecologists Of Canada Guidelines on screening for cervical cancer.

\begin{tabular}{|c|c|c|c|c|c|}
\hline \multicolumn{2}{|c|}{ Classification } & \multicolumn{4}{|c|}{ Society Of Obstetricians And Gynecologists Of Canada } \\
\hline \multirow{2}{*}{\multicolumn{2}{|c|}{ Overview }} & $<21$ year old & 21 - 30year old & 31 - 65year old & $>65 y e a r$ old \\
\hline & & $\begin{array}{l}\text { No cytological screening } \\
\text { recommended }\end{array}$ & & & \\
\hline & ASCUS & Repeat cytology & \multicolumn{3}{|c|}{$\begin{array}{l}\text { Do colposcopy within 12week: if a lesion was found: do a biopsy, if no lesion was found: do a biopsy } \\
\text { of the transformation zone }\end{array}$} \\
\hline & ASC-H & & \multicolumn{3}{|c|}{ Colposcopy within 6 weeks } \\
\hline & LSIL & Repeat cytology & \multicolumn{3}{|c|}{$\begin{array}{l}\text { Do colposcopy within } 12 \text { week: if a lesion was found: do a biopsy, if no lesion was found: do a biopsy } \\
\text { of the transformation zone }\end{array}$} \\
\hline & HSIL & Colposcopy within 4 weeks & \multicolumn{3}{|c|}{$\begin{array}{l}\text { Do colposcopy within } 4 \text { weeks, if no lesion found: do endocervical curettage/directed biopsy. If lesion } \\
\text { was found and transformation zone was not seen and endocervical curettage and/or biopsy were } \\
\text { negative: do a diagnostic excisional procedure }\end{array}$} \\
\hline & AGC & & \multirow{2}{*}{\multicolumn{3}{|c|}{$\begin{array}{l}\text { Do colposcopy and endocervical curettage within } 6 \text { weeks (plus endometrial sampling if bleeding and } \\
\text { age more than 35years). } \\
\text { If no lesion was found on colposcopy: do a diagnostic excisional procedure }\end{array}$}} \\
\hline & AIS & & & & \\
\hline \multirow{5}{*}{ Histology } & HPV on biopsy & & $\begin{array}{l}\text { 1) no HPV test as screening } \\
\text { 2) HPV positive and cytology negative }=>\text { provincial } \\
\text { routine }\end{array}$ & $\begin{array}{l}\text { Positive HPV an } \\
=>\text { HPV and cytc }\end{array}$ & $\begin{array}{l}\text { ytology negative } \\
\text { y at } 12 \text { months }\end{array}$ \\
\hline & CIN 1 & & \multicolumn{3}{|c|}{ Observation and repeat cytology or do colposcopy at 12 months } \\
\hline & CIN 2 & & \multirow{2}{*}{\multicolumn{3}{|c|}{$\begin{array}{l}\text { Excisional procedure } \\
\text { If positive margin: colposcopy and directed Biopsy and/or endocervical curettage } \\
\text { If recurrent or persistent lesions: Excision }\end{array}$}} \\
\hline & CIN 3 & & & & \\
\hline & & & \multicolumn{3}{|c|}{$\begin{array}{l}\text { Diagnostic excisional procedure OR type } 3 \text { transformation zone excision } \\
\text { If positive margin: do a second excisional procedure }\end{array}$} \\
\hline
\end{tabular}




\begin{tabular}{|c|c|c|c|}
\hline \multicolumn{2}{|c|}{ Classification } & \multicolumn{2}{|l|}{ Singapore guidelines } \\
\hline \multirow{2}{*}{\multicolumn{2}{|c|}{ Overview }} & $25-65$ & $>65$ \\
\hline & & PAP smear once every 3years (more frequently if high risk) & \multirow{2}{*}{$\begin{array}{c}\text { No need for further screening if PAP smear at age } \\
65 \text { was negative and previous negative smear in } \\
\text { last 3years }\end{array}$} \\
\hline & ASCUS & $\begin{array}{l}\text { Repeat smear in } 6 \text { months: if positive refer to colposcopy / if negative repeat } \\
\text { again in } 6 \text { months, then if still negative return to routine screening }\end{array}$ & \\
\hline & ASC-H & Refer to colposcopy & \\
\hline & LSIL & $\begin{array}{l}\text { 1. If mild dyskaryosis or not otherwise specified: colposcopy } \\
\text { 2. If HPV effect: repeat in 6months: } \\
\text { a. If negative: repeat in 1year > if still negative resume routine screening } \\
\text { b. If still HPV effect or more severe abnormality: colposcopy }\end{array}$ & \\
\hline & HSIL & $\begin{array}{l}\text { 1. If moderate or severe dyskaryosis: colposcopy } \\
\text { 2. If severe dyskaryosis and cannot rule out invasive Cancer: urgent } \\
\text { colposcopy }\end{array}$ & \\
\hline & AGC & Refer to colposcopy & \\
\hline & AIS & Endocervical adenocarcinoma in-situ: colposcopy & \\
\hline & Inflammatory smear & $\begin{array}{l}\text { 1. Treat any infection or atrophy then repeat in } 4-6 \text { months: } \\
\text { 2. 2nd smear has similar changes: Treat any infection or atrophy then repeat } \\
\qquad \text { in } 4-6 \text { months } \\
\text { 3. 3rd smear has similar changes: refer to gynecologist } \\
\text { Note: once changes resolve after } 1 \text { st or } 2 \text { nd smear: resume routine screening }\end{array}$ & \\
\hline \multirow{4}{*}{ Histology } & HPV on biopsy & $\begin{array}{l}\text { 1. Treat if any } \mathrm{CIN} \text { or condylomas present } \\
\text { 2. HPV but no CIN: yearly PAP smear } x 2>\text { if negative }>\text { return to routine } \\
\text { screening }\end{array}$ & \\
\hline & CIN 1 & $\begin{array}{l}\text { Controversial: } 2 \text { options available: } \\
\text { 1. Treat with ablation or excision then follow-up with PAP smear at } 3-6 \text { months, } \\
\text { PAP smear and colposcopy at } 12 \text { months }>\text { yearly PAP smear } x 4>\text { return to } \\
\text { routine screening } \\
\text { 2. Observe and repeat PAP smear and colposcopy }+/ \text { - biopsy in } 6 \text { months }\end{array}$ & \\
\hline & CIN 2 & \multirow{2}{*}{$\begin{array}{l}\text { After treatment screen with PAP smear at } 3-6 \text { months }>\text { PAP smear and } \\
\text { colposcopy at } 12 \text { months }>\text { PAP smear } 6 \text { monthly for } 2 \text { nd year }>\text { yearly PAP } \\
\text { smear }\end{array}$} & \\
\hline & CIN 3 & & \\
\hline
\end{tabular}

- If colposcopy was positive and biopsy was done: For $\geq \mathrm{CIN} 2$ treat with cryotherapy or LEEP and then do a follow-up screen in a 1-year time. However, if biopsy shows a $\leq$ CIN1 repeat screening in 3-year time.

- If cancer was suspected: Refer the patient for appropriate diagnosis and treatment [9].

- Second, if screening was done via cytology (PAP smear), the following algorithm is used:

- If cytology negative: Repeat screening 3-5yearly.

\section{If cytology positive ( $\geq$ ASCUS): Do colposcopy}

- If colposcopy was negative: Repeat screening in 3years' time.

- If colposcopy was positive and no biopsy was done: Treat with cryotherapy if eligible or with LEEP if not. Later, do a follow-up screen in a 1 year time.

\section{If colposcopy was positive and biopsy was done}

For $\geq$ CIN2 treat with cryotherapy or LEEP and then do a follow-up screen in a 1-year time. However, if biopsy shows a $\leq$ CIN1 repeat screening in 3-year time.

If cancer was suspected: Refer the patient for appropriate diagnosis and treatment [9].
For those recommendations, cryotherapy is the superior treatment method. However, the WHO specifies eligibility criteria for cryotherapy that requires the entire lesion and the squamocolumnar junction to be visible and the lesion should not cover more than $75 \%$ of the ectocervix. If this criteria was not met, LEEP would be the alternative option [9].

Please see table 14 which summarizes the discussed guideline.

\section{The European guidelines for quality assurance in cervi- cal cancer screening}

The recent guidelines published in 2015 indicate that the use of HPV alone as a screening test for cervical cancer is more beneficial than cytology. They also show that co-testing is not superior to HPV testing alone as it may lead to an increase in costs and unnecessary referrals to colposcopy. However, this is only applicable for the ages between $30-65$, as beyond this range, cytology remains the primary screening tool [10]. If a HPV test was negative, re-screening should be done at least 5-yearly. Moreover, not all HPV-positive tests will be referred to colposcopy. Cytology will be done on the same sample collected. If cytology was negative, the test will be repeated in 6-12months' time. If cytology indicated ASC-H, HSIL or AIS, the patient will be referred immediately to colposcopy. If cytology indicated ASCUS, AGC or LSIL, either the test will be repeated in 6-12months' time or the patient will be referred 
Table 14: World Health Organization (WHO) Guidelines on screening for cervical cancer.

\section{Classification WHO Guidelines}

The new WHO guidelines recommend a screen-and-treat approach for cervical neoplasms. This strategy compromise of screening for cervical cancer via one of the following methods; HPV test, VIA or cytology (Pap smear). Once a screening test has been done and showed a positive result, treatment will be initiated via one of the following methods; cryotherapy, LEEP/LLETZ or CKC.

Overview $<30$ year old Screening not recommended

\section{0-49year old}

$30 y e a r s$ is the age recommended to initiate screening for cervical cance

- If HPV negative: repeat screening every 5years minimum

- If HPV positive > do VIA to assess eligibility for treatment with cryotherapy and to exclude a cervical cancer

If VIA negative: repeat screening in 1-year time and then 3-5yearly

- If VIA positive: Treat with cryotherapy if eligible or with LEEP if not. Later, do a follow-up screen in a 1year time

Screening with HPV test, followed by VIA or colposcopy

- If cancer was suspected: refer the patient for appropriate diagnosis and treatment

Alternatively, if HPV test was positive, colposcopy can be done instead of VIA:

- If colposcopy was negative: repeat screening in 3year time

- If colposcopy was positive and no biopsy was done: Treat with cryotherapy if eligible or with LEEP if not. Later, do a follow-up screen in a 1year time

- If colposcopy was positive and biopsy was done: for $\geq C I N 2$ treat with cryotherapy or LEEP and then do a follow-up screen in a 1-year time. However, if biopsy shows a $\leq$ CIN1 repeat screening in 3-year time.

- If cancer was suspected: refer the patient for appropriate diagnosis and treatment

If cytology negative: repeat screening 3-5yearly

- If cytology positive ( $\geq$ ASCUS): do colposcopy:

- If colposcopy was negative: repeat screening in 3year time

- If colposcopy was positive and no biopsy was done: Treat with cryotherapy if eligible or with LEEP if not. Later, do a follow-up screen in a 1year time

Screening with cytology (PAP smear) followed by colposcopy
- If colposcopy was positive and biopsy was done: for $\geq C I N 2$ treat with cryotherapy or LEEP and then do a follow-up screen in a 1-year time. However, if biopsy shows a $\leq$ CIN1 repeat screening in 3-year time.

- If cancer was suspected: refer the patient for appropriate diagnosis and treatment to colposcopy [10]. Please see table 15 , which summarizes the discussed guideline.

\section{Human Papilloma Virus}

\section{Screening and Vaccination}

- Human Papilloma Virus (HPV) is a double-stranded DNA virus with a well-established connection with cervical cancer. Almost all cases of cervical cancer are linked to HPV (99\%). In particular, HPV 16 and 18 are attributed to $50 \%$ and $20 \%$ of cervical cancer cases, respectively [11].

- High-risk HPV viruses include HPV 16, 18, 31, 33, 35, 39, $45,51,52,56,58,59$ and 66.

- Not only is HPV linked to cervical cancer, but also to vaginal, vulvular, oropharyngeal and anal cancers. Anogenital wart is also another complication [12].

- HPV vaccines include bivalent and quadrivalent vaccines that contain HPV 16, 18 and HPV 6, 11, 16 and 18 , respectively.

- In 2014, the Food and Drug Administration (FDA) approved a 9-valent HPV vaccine which includes 4 genotypes of HPV vaccine; 6, 11, 16 and 18 [13].

- The timing for vaccination relies on the age. The best time to start vaccination is prior to sexual intercourse. The target age group for HPV vaccination is young girls between the ages 9years and 14years.
Table 15: The European Guidelines For Quality Assurance In Cervical Cancer Screening.

\begin{tabular}{|c|c|c|c|}
\hline Classification & The European Guidelines For Quality Assurance In Cervical \\
Cancer Screening
\end{tabular}

- The vaccine regimen depends on the age at which the vaccine is to be given. For example, if the female was less than 15years of age, the vaccine is given as 2 doses 6-months apart. However, if the female was more than 15years of age, a 3-doses regimen is recommended [14].

- Regardless of the vaccination status, women will still have to be screened as per the routine screening guidelines. This is explained by the fact that $10 \%-30 \%$ of the cervical cancer cases are caused by other types of HPV that are not included in the vaccines. Also, there is a possibility that the vaccinated woman was already 
infected with the virus before the vaccine was delivered [10-15].

- The efficacy of vaccination depends on whether the individual was previously infected or not. The best protection lies in those who were never infected. Vaccination is more effective in younger women than older ones though older women would still benefit from vaccination. The immunoprotection of $\mathrm{HPV}$ vaccine lasts approximately 84 months. Antibodies developed against HPV after vaccination is found to last about 10years.

- HPV vaccination is not recommended in pregnancy due to few data concerning its safety. However, no increased risk of adverse pregnancy outcomes was noted in patients who have been vaccinated.

- HPV vaccination is recommended in immunocompromised patients. 3 doses should be administered for all patients through 26years old.

- The risks associated with vaccination are minimal. Parents might think that vaccination might lead to sexual disinhibition but surveys performed suggest that there was no increase in risky sexual behavior. Hence, HPV vaccination should be promoted and administered to both men and women.

\section{Cervical cancer screening and HPV in Bahrain}

In Bahrain, a recent report was published with local statistics of cervical cancer and HPV. It indicated an annual incidence of 22 for cervical cancer in Bahrain. It also demonstrated the prevalence of HPV infection among the following: normal cytology (2.2), low-grade cervical lesions (24), high-grade cervical lesions (52.3) and cervical cancer (72.4) [16].

Bahrain is one of the countries with an established screening program for cervical cancer. The guidelines state to screen all women between the ages 30 and 65years once every 5years. However, currently, there is no established HPV vaccination program in Bahrain [16].

\section{References}

1. Feldman S, Goodman A, Peipert JF (2017) Screening for cervical cancer. Link: https://bit.ly/2TzRdl8

2. Frumovitz M (2017) Invasive cervical cancerL: Epidemiology, risk factors, clinical manifestations and diagnosis. Link: https://bit.ly/39CWcgL

3. Peirson L, Fitzpatrick-Lewis D, Ciliska D, Warren R (2013) Screening for cervical cancer: a systematic review and meta- analysis. Syst Rev 2: 35. Link: https://bit.ly/330M8vD

4. Prevention CoDCa (2015) Cervical Cancer Screening Guidelines for AverageRisk Women. Link: https://bit.ly/2vPzHGM

5. Care CTFoPH (2013) Recommendations on screening for cervical cancer CMAJ 185: 35-45. Link: https://bit.ly/2TxHu52
6. Ho Tew Hong ea. Management guidelines for abnormal pap smear and preinvasive disease of the cervix. Link: http://bit.ly/38zlrPT

7. Clinical Knowledge Summaries N (2015) Cervical Screening

8. Saslow D, Solomon D, Lawson HW, Killackey M, Kulasingam SL, et al. (2012) American Cancer Society, American Society for Colposcopy and Cervical Pathology, and American Society for Clinical Pathology Screening Guidelines for the Prevention and Early Detection of Cervical Cancer. CA Cancer J Clin 62 147-172. Link: https://bit.ly/2ls8nky

9. WHO (2013) WHO guidelines for screening and treatment of precancerous lesions for cervical cancer prevention. Link: https://bit.ly/39zZguf

10. Arbyn M, Anttila A, Jordan J, Ronco G, Schenck U, et al. (2010) European Guidelines for Quality Assurance in Cervical Cancer Screening. Second Edition-Summary Document. Ann Oncol 21: 448-458. Link: https://bit.ly/2lutcvA

11. Palefsky JM (2017) Human papillomavirus infections: Epidemiology and disease associations. Link: https://bit.ly/2v1Lgds

12. Cutts FT, Franceschi S, Goldie S, Castellsague X, de Sanjose S, et al. (2007) Human papillomavirus and HPV vaccines: a review. Bull World Health Organ 85: 649-732. Link: https://bit.ly/2TSKsjL

13. Petrosky E, Bocchini JA, Hariri S, Chesson H, Curtis CR, et al. (2015) Use of 9-Valent Human Papillomavirus (HPV) Vaccine: Updated HPV Vaccination Recommendations of the Advisory Committee on Immunization Practices. MMWR Morb Mortal Wkly Rep 64: 300-304. Link: https://bit.ly/3cLlieq

14. WHO (2017) Human papillomavirus (HPV). Link: https://bit.ly/3cJGWAP

15. Prevention CoDCa (2015) Rationale for Screening Recommendations.

16. Bruni L, Albero G, Serrano B, Mena M, Gómez D, et al. (2017) ICO Information Centre on HPV and Cancer (HPV Information Centre). Human Papillomavirus and Related Diseases Report in Bahrain. Link: https://bit.ly/2v5wmD3

Discover a bigger Impact and Visibility of your article publication with Peertechz Publications

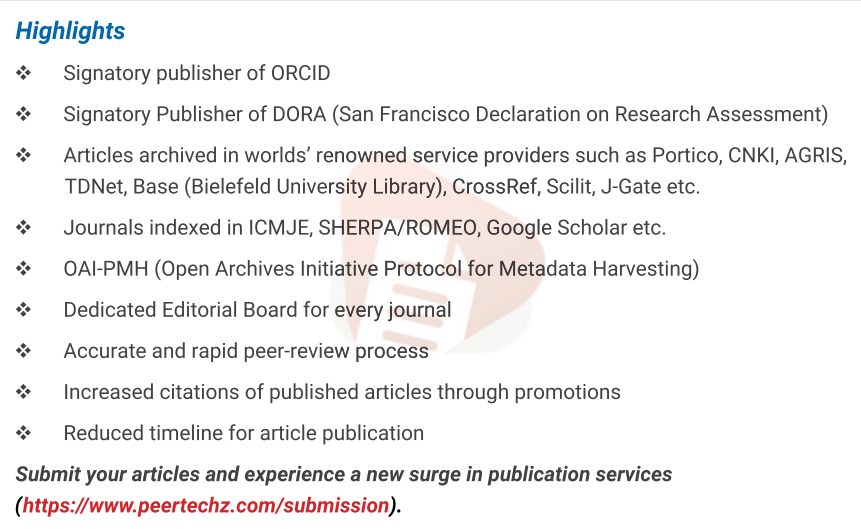

Peertechz journals wishes everlasting success in your every endeavours.

Copyright: @ 2020 Ismail MS, et al. This is an open-access article distributed under the terms of the Creative Commons Attribution License, which permits unrestricted use distribution, and reproduction in any medium, provided the original author and source are credited. 